\title{
Non-Communicable Diseases in Medan City 2016
}

\author{
Erna Mutiara ${ }^{1}$, Syarifah ${ }^{2}$ \\ ${ }^{1}$ Department of Population and Biostatistics \\ Faculty of Public Health, Universitas Sumatera Utara \\ Medan, Indonesia \\ 2Department of Health Education and Behavioral Science \\ Faculty of Public Health, Universitas Sumatera Utara \\ Medan, Indonesia \\ Email: erna3@usu.ac.id
}

\begin{abstract}
Non-communicable disease (NCD) is the leading cause of death globally. In low-and-middle-income countries, of all deaths in people under 60, 29\% are due to NCD, whereas in developed countries, it accounts for $13 \%$ of deaths. The high problem of NCD in Medan City requires adequate and comprehensive control effort through promotion, early detection, treatment, and rehabilitation. These efforts need to be supported by the provision of accurate data and information. The purpose of this study was to provide an overview of NCD Diseases in Medan City. This research is a descriptive research using secondary data from Medan City Health Office in 2016. The results showed that during 2016 in Medan City Health Office, hypertension, coronary heart disease (CHD), diabetes mellitus and obesity were the four most NCD. Hypertension was found mostly in the working area of the Helvetia health center (7212 cases), CHD (2109 cases) and type II diabetes mellitus (4737 cases). Type I diabetes mellitus was most prevalent in the working area of Kota Matsum health center (631 cases). Gestational diabetes was the most common in the working area of Tegal Sari health center (34 cases). The obesity was most common in the working area of Teladan health center (356 cases). Considering the very high cases of hypertension in Medan City, it is suggested to the community to pay attention to risk factors and how to prevent hypertension.
\end{abstract}

Keywords: communicable diseases; risk factors; hypertension; coronary heart disease; diabetes mellitus

\section{INTRODUCTION}

Non-communicable disease (NCD) is the leading cause of death globally. WHO data show that of the 57 million deaths occurring in the world in 2008, 36 million or nearly two-thirds were caused by Non-communicable diseases. NCD also kills the population at a younger age. In low and middle-income countries, of all deaths in people under $60,29 \%$ are caused by NCD, whereas in developed countries, it accounts for $13 \%$ of deaths. The proportion of causes of PTM deaths in people younger than 70 years, cardiovascular disease is the biggest cause (39\%), followed by cancer (27\%), whereas chronic respiratory illness, gastrointestinal illness, and other PTM together account for about 30\%, and $4 \%$ of deaths caused by diabetes [1].

According to the World Health Organization WHO, deaths from non-communicable diseases (NCD) are expected to continue rising worldwide, the largest increase will occur in middle and poor countries. More than two-thirds (70\%) of the global population will die from noncommunicable diseases such as cancer, heart disease, stroke, and diabetes. In total, by 2030 it is predicted there will be 52 million deaths per year from non-communicable diseases, up 9 million from 38 million at present. On the other hand, deaths from infectious diseases such as malaria, tuberculosis or other infectious diseases will decline, from 18 million currently to 16.5 million by 2030.4 In middle and poor countries NCD will be responsible for three times of the year Lost life and disability (Disability-adjusted life years = DALYs) and almost five times the deaths of infectious, maternal, perinatal and nutritional diseases [1].

Globally, regionally and nationally by 2030 , the epidemiological transition from infectious diseases to non-infectious diseases is increasingly apparent. It is projected that the amount of morbidity from non-communicable diseases and accidents will increase and infectious diseases will decline. PTM such as cancer, heart, chronic obstructive pulmonary and chronic lung, as well as other chronic diseases will increase significantly by 2030. Meanwhile, infectious diseases such as tuberculosis, HIV/AIDS, Malaria, Diarrhea and other infectious diseases are predicted to decrease by 2030 Increased PTM incidence is associated with increased risk factors due to lifestyle changes along with the more 
modern world developments, population growth and increased life expectancy [2].

Indonesia in the last few decades faces the problem of triple burden diseases. On the one hand, infectious diseases are still a problem marked by frequent outbreaks of certain infectious diseases, reemerging diseases, and the emergence of new-emergy diseases such as HIV/AIDS, Avian Influenza, Swine Flu and Nipah Disease. On the other hand, NCD shows an increasing trend over time. According to the results of Basic Health Research (Riskesdas) 2007, 2013 and Household Health Survey 1995 and 2001, it appears that for 12 years (19952007) there has been an epidemiological transition where deaths from non-communicable diseases are increasing, whereas death from communicable disease is decreasing. This phenomenon is predicted to continue [3-7].

The number of deaths from noncommunicable diseases (NCD) in Indonesia continues to increase. It changed the trend of the cause of death in the 1990s, the majority of which are infectious diseases or epidemics. Changes in lifestyle and mobility are considered to be a major factor in the high mortality caused by NCD. Based on data collected by the Ministry of Health, in 1990, the mortality rate due to NCD in Indonesia was at $37 \%$. The number continues to increase. In 2000, deaths from NCD to 49\%. Subsequently, in 2010 the figure again increased to $58 \%$. Finally, until mid-2015, it is known total deaths from non-communicable diseases (NCD) in Indonesia continues to increase. It changed the trend of the cause of death in the 1990s, the majority of which are infectious diseases or epidemics. Changes in lifestyle and mobility are considered to be a major factor in the high mortality caused by PTM.

Prevalence of NCD in Indonesia based on Riskesdas 2013, hypertension age > 18 years (25.8\%), Coronary heart disease (CHD) age $\geq 15$ years $(1.5 \%)$, heart failure $(0.3 \%)$, chronic renal failure $(0.2 \%)$, kidney stones $(0.6 \%)$, rheumatism $(24.7 \%)$, stroke (12.1\%), injuries of all ages (8.2\%), asthma (4.5\%), Chronic Obstructive Lung (COPD) age $\geq 30$ years (3.8\%), Cancer (1.4 \%o), diabetes mellitus (2.1\%), hyperthyroid age $\geq 15$ years on the basis of diagnosis $(0.4 \%)$, and injury due to land transportation (47.7\%). While some risk factors of NCD, obesity in men age > 18 years $(19.7 \%)$ and in women $(32.9 \%)$, central obesity $(26.6 \%)$, tobacco consumption age $\geq 15$ years $(36.3 \%)$, less vegetable consumption (93.5\%). Prevalence of NCD in North Sumatera Province based on
Riskesdas 2013, hypertension (6.7\%), CHD $(1.1 \%)$, heart failure $(0.3 \%)$, chronic renal failure $(0.2 \%)$, kidney stones $(0,3 \%)$, stroke $(10.3 \%)$, asthma (2.4\%), COPD (3.6\%), cancer (1.0\%), diabetes mellitus (2.3\%), hyperthyroid (0.3\%), and joint disease (19.2\%).

The high problem of NCD in Medan City requires adequate and comprehensive control effort through promotion, early detection, treatment, and rehabilitation. These efforts need to be supported by the provision of accurate data and information. So far, one of the efforts has been done, among others, NCD surveillance activities. However, despite the presence of NCD surveillance, the number of cases of some NCDs, in Medan City was still high. This research tried to describe NCD in Medan City according to some risk factors and the working area of the health center, that has been done this time only the global description about NCD overall per year.

This research tries to understand the distribution of NCD cases and create a map of some cases of NCD (hypertension, CHD, diabetes mellitus, and obesity) in Medan. With the map of the distribution of NCD cases, it is expected to assist the implementation of health system management to plan, monitor and evaluate health programs or design interventions from a geospatial perspective.

\section{METHODS}

\section{A. Research Design}

This research is descriptive research to get NCD description in Medan City by using secondary data.

\section{B. Population and Sample}

Population and sample of this research were data of monthly NCD recapitulation in Medan City from Medan Municipal Health Office.

\section{Data Analysis}

Data analysis was done in the form of descriptive analysis to see case description and risk factor according to man, place and time, in the form of frequency distribution table and graph.

\section{RESULTS AND DISCUSSION}

From data recorded during 2016 in Medan City Health Office, four (4) cases of NCD most commonly suffered were hypertension, CHD, diabetes mellitus and obesity. Description of the case of NCD in Medan City can be seen in Table 1 below. 
TABLE I. Description of Non-Communicable Disease CASE (NCD) IN MEDAN CITY JANUARY - DECEMBER 2016

\begin{tabular}{|c|c|c|}
\hline Disease & $I C D X$ & Total \\
\hline Hypertension & I10 & 61553 \\
\hline Coronary Heart Disease & I24.0 & 8950 \\
\hline Diabetes Mellitus & & 3280 \\
\hline a. DM Type I & E10 & 2770 \\
\hline b. DM Type II & E11 & 34755 \\
\hline c. DM Gestational & 024 & 154 \\
\hline Obesity & E66 & 2023 \\
\hline Thyroid & & 151 \\
\hline a. Hypothyroid & E05 & 26 \\
\hline b. Hyperthyroid & E03 & 305 \\
\hline Stroke & & 647 \\
\hline a. Haemorrhagic Stroke & I60-I62 & 429 \\
\hline b. Non-Haemorrhagic Stroke & I63 & 2018 \\
\hline Bronchial Asthma & $\mathrm{J} 45$ & 5571 \\
\hline $\begin{array}{l}\text { Chronic Obstructive Pulmonary Disease } \\
\text { (COPD) }\end{array}$ & $\mathrm{J} 44$ & 3871 \\
\hline Osteoporosis or Rheumatik & M81 & 4593 \\
\hline Chronic Kidney Disease & N00-N19 & 1815 \\
\hline Thalassemia & & 43 \\
\hline Systemic Lupus Erythematosus (SLE) & & 21 \\
\hline Cancer & & 15 \\
\hline a. Mammae Cancer & $\mathrm{C} 50$ & 609 \\
\hline b. Retinoblastoma Cancer & C69 & 28 \\
\hline c. Cervix Cancer & C53 & 175 \\
\hline d. Lung Cancer & C34 & 78 \\
\hline e. Colorectal Cancer & C18-C20 & 48 \\
\hline f. Leukemia & C91-C95 & 10 \\
\hline g. Prostatic Cancer & C61 & 59 \\
\hline h. Nasopharynx Cancer & C11 & 35 \\
\hline i. Skin Cancer & C43-C44 & 1 \\
\hline j. Liver Cancer & $\mathrm{C} 22$ & 7 \\
\hline Injuries from traffic accidents & V01-V99 & 993 \\
\hline Injuries resulting from domestic violence & $\mathrm{X} 60-\mathrm{Y} 09$ & 5 \\
\hline Another injuries & W00-X59 & 1094 \\
\hline
\end{tabular}

When it was mapped, diabetes mellitus was found most commonly in the subdistrict of Medan Helvetia, Medan Tembung, and Medan Perjuangan as can be seen in the figure below.

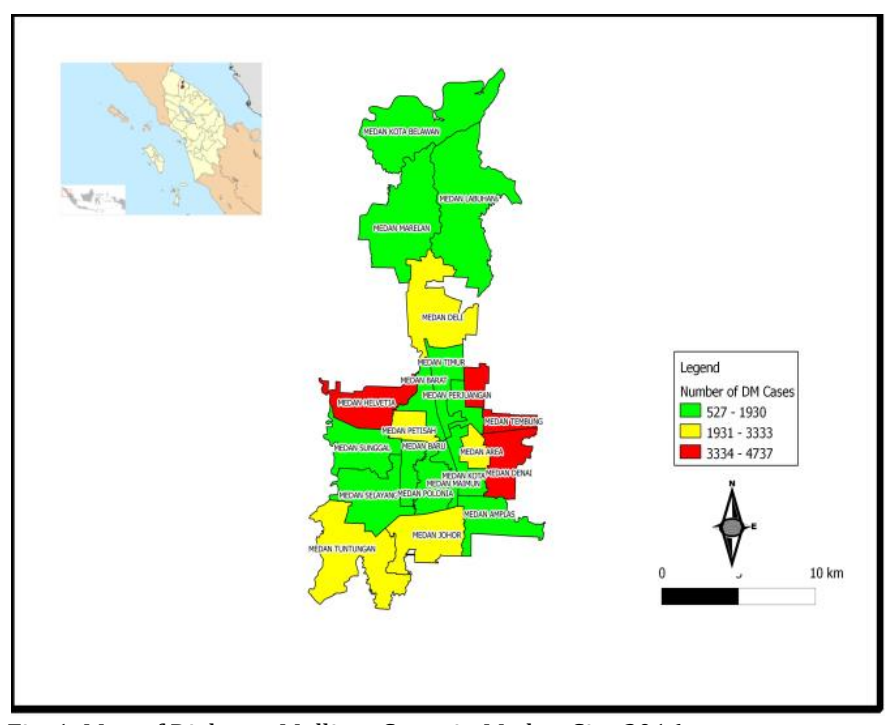

Fig. 1. Map of Diabetes Mellitus Cases in Medan City 2016

When it was viewed by sex, women were more likely to suffer from hypertension and type II diabetes mellitus (Fig 2).

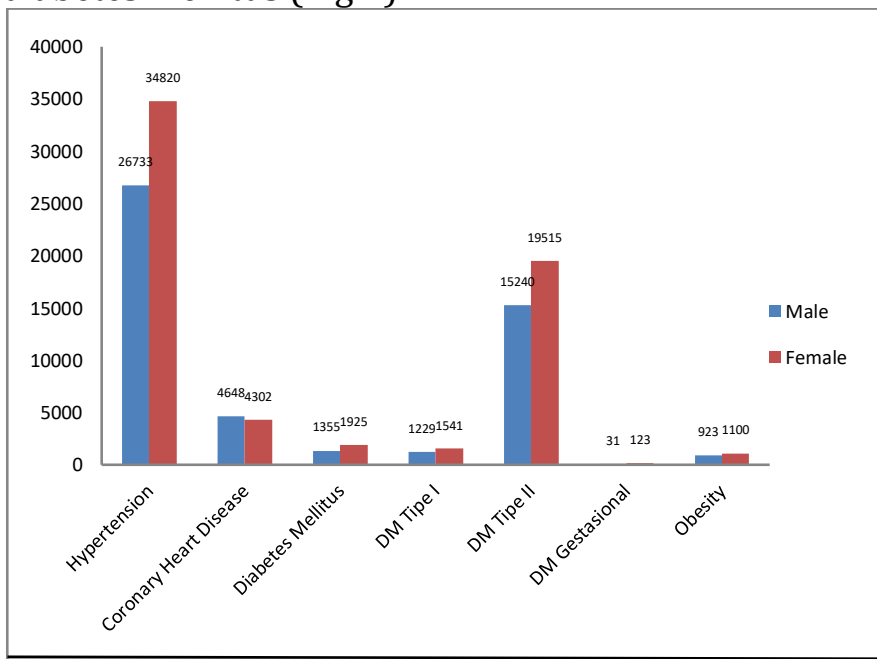

Fig. 2. The Most Non-Communicable Diseases by Sex in the Medan City 2016

Of the 21 sub-districts in Medan City, the proportion of the most suffering from hypertension compared with the number of population is Medan Petisah Subdistrict.

TABLE II. Proportion of The Most Non-Communicable Diseases BY Population AND Sub-District in MEDAN City 2016

\begin{tabular}{|l|c|c|c|c|c|}
\hline \multicolumn{1}{|c|}{$\begin{array}{c}\text { Sub- } \\
\text { district }\end{array}$} & $\begin{array}{c}\text { Populatio } \\
\boldsymbol{n}\end{array}$ & $\begin{array}{c}\text { \% } \\
\text { Hyper- } \\
\text { tension }\end{array}$ & $\begin{array}{c}\text { \% } \\
\text { CHD }\end{array}$ & $\begin{array}{c}\% \\
\text { DM }\end{array}$ & $\begin{array}{c}\% \\
\text { obesit } \\
\boldsymbol{y}\end{array}$ \\
\hline $\begin{array}{l}\text { Medan } \\
\text { Tuntunga } \\
\mathrm{n}\end{array}$ & 86,425 & 3.53 & 0.38 & 2.23 & 0.00 \\
\hline $\begin{array}{l}\text { Medan } \\
\text { Johor }\end{array}$ & 133,577 & 2.98 & 0.00 & 1.75 & 0.00 \\
\hline $\begin{array}{l}\text { Medan } \\
\text { Amplas }\end{array}$ & 126,340 & 0.90 & 0.01 & 0.57 & 0.00 \\
\hline $\begin{array}{l}\text { Medan } \\
\text { Denai }\end{array}$ & 146,388 & 4.31 & 0.05 & 2.31 & 0.03 \\
\hline $\begin{array}{l}\text { Medan } \\
\text { Area }\end{array}$ & 99,021 & 5.03 & 0.08 & 2.06 & 0.00 \\
\hline $\begin{array}{l}\text { Medan } \\
\text { Kota }\end{array}$ & 74.461 & 0,65 & 1,72 & 2,14 & 0,49 \\
\hline \begin{tabular}{l} 
Medan \\
\hline
\end{tabular} & 40,690 & 2.50 & 0.68 & 2.17 & 0.01 \\
\hline
\end{tabular}




\begin{tabular}{|l|c|c|c|c|c|}
\hline \multicolumn{1}{|c|}{$\begin{array}{c}\text { Sub- } \\
\text { district }\end{array}$} & $\begin{array}{c}\text { Populatio } \\
\boldsymbol{n}\end{array}$ & $\begin{array}{c}\text { \% } \\
\text { Hyper- } \\
\text { tension }\end{array}$ & $\begin{array}{c}\text { \% } \\
\text { CHD }\end{array}$ & $\begin{array}{c}\text { \% } \\
\text { DM }\end{array}$ & $\begin{array}{c}\text { \% } \\
\text { obesit } \\
\boldsymbol{y}\end{array}$ \\
\hline Maimun & & 1.69 & 0.19 & 1.08 & 0.00 \\
\hline $\begin{array}{l}\text { Medan } \\
\text { Polonia }\end{array}$ & 56,513 & 4.70 & 1.48 & 3.06 & 0.01 \\
\hline $\begin{array}{l}\text { Medan } \\
\text { Baru }\end{array}$ & 40,560 & 1.07 & 0.06 & 0.95 & 0.02 \\
\hline $\begin{array}{l}\text { Medan } \\
\text { Selayang }\end{array}$ & 107,831 & 115,837 & 0.11 & 0.70 & 0.02 \\
\hline $\begin{array}{l}\text { Medan } \\
\text { Sunggal }\end{array}$ & 151,581 & 4.76 & 1.39 & 3.13 & 0.14 \\
\hline $\begin{array}{l}\text { Medan } \\
\text { Helvetia }\end{array}$ & 63,390 & 6.02 & 1.30 & 3.48 & 0.12 \\
\hline $\begin{array}{l}\text { Medan } \\
\text { Petisah }\end{array}$ & 72,717 & 4.50 & 1.09 & 2.11 & 0.02 \\
\hline $\begin{array}{l}\text { Medan } \\
\text { Barat }\end{array}$ & 111,438 & 1.13 & 0.07 & 0.59 & 0.13 \\
\hline $\begin{array}{l}\text { Medan } \\
\text { Timur }\end{array}$ & 95,936 & 1.74 & 1.51 & 1.68 & 0.02 \\
\hline $\begin{array}{l}\text { Medan } \\
\text { Perjuanga } \\
\text { n }\end{array}$ & 137,239 & 3.65 & 0.14 & 3.09 & 0.13 \\
\hline $\begin{array}{l}\text { Medan } \\
\text { Tembung }\end{array}$ & 184,762 & 3.11 & 0.08 & 1.32 & 0.16 \\
\hline $\begin{array}{l}\text { Medan } \\
\text { Deli }\end{array}$ & 118,551 & 0.70 & 0.00 & 0.63 & 0.00 \\
\hline $\begin{array}{l}\text { Medan } \\
\text { Labuhan }\end{array}$ & 167,984 & 0.79 & 0.16 & 0.78 & 0.20 \\
\hline $\begin{array}{l}\text { Medan } \\
\text { Marelan }\end{array}$ & 98,167 & 1.00 & 0.16 & 0.54 & 0.02 \\
\hline $\begin{array}{l}\text { Medan } \\
\text { Belawan }\end{array}$ & 139 \\
\hline
\end{tabular}

The description of noncommunicable diseases in Medan City by age group and gender can be seen in the following table.

TABLE III. The Most Non-Communicable Disease CASES By AgE GRoup AND SEX IN MEDAN CiTy 2016

\begin{tabular}{|c|c|c|c|c|c|c|c|c|}
\hline \multirow{2}{*}{ Disease } & \multicolumn{2}{|c|}{$\begin{array}{c}<18 \\
\text { years }\end{array}$} & \multicolumn{2}{|c|}{$18-44$ years } & \multicolumn{2}{|c|}{$45-54$ years } & \multicolumn{2}{|c|}{$55+$ years } \\
\hline & $M$ & $F$ & $M$ & $F$ & $M$ & $F$ & $M$ & $F$ \\
\hline $\begin{array}{l}\text { Hyper- } \\
\text { tension }\end{array}$ & 19 & 45 & 2658 & 3837 & 6535 & 9080 & $\begin{array}{r}1654 \\
2 \\
\end{array}$ & $\begin{array}{r}2082 \\
5 \\
\end{array}$ \\
\hline CHD & 0 & 11 & 398 & 442 & 1148 & 1147 & 3236 & 2829 \\
\hline DM & 0 & 0 & 92 & 146 & 226 & 344 & 693 & 943 \\
\hline $\begin{array}{l}\text { DM } \\
\text { Tipe I }\end{array}$ & 2 & 8 & 144 & 188 & 317 & 432 & 710 & 841 \\
\hline $\begin{array}{l}\text { DM } \\
\text { Gesta- } \\
\text { tional } \\
\end{array}$ & 0 & 1 & 6 & 4 & 8 & 64 & 17 & 44 \\
\hline Obesity & 69 & 73 & 132 & 234 & 233 & 307 & 345 & 373 \\
\hline
\end{tabular}

From the Table III showed that there were hypertension patients aged 18 years and below, most patients with hypertension aged 55 years and above.

Map of cases of hypertension in Medan City can be seen in the following figure.

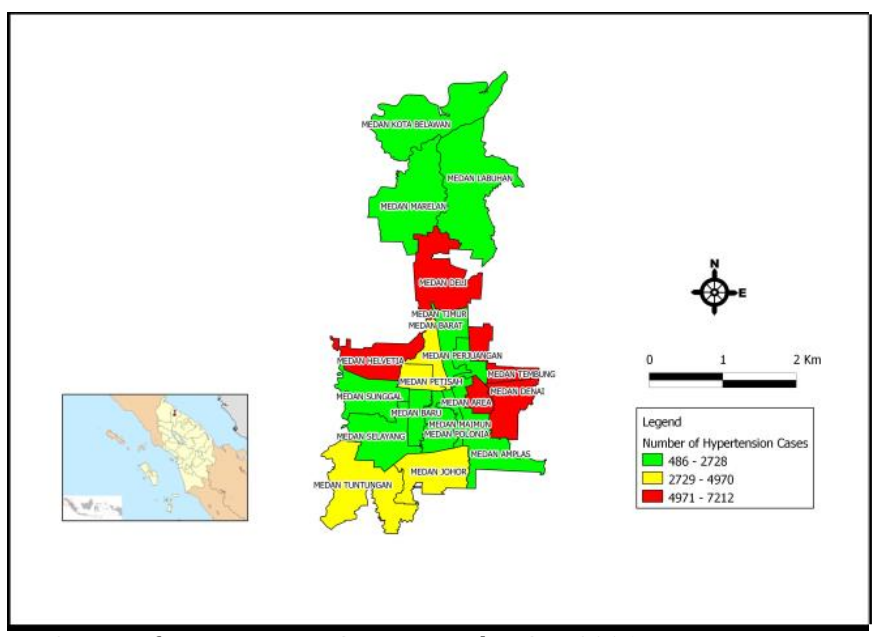

Fig. 3. Map of Hypertension Cases in Medan City 2016

Hypertension cases mostly are found in Medan Helvetia, Medan Deli, Medan Tembung, Medan Denai and Medan Area.

In sub-Saharan Africa, measurement of blood pressure from cross-sectional studies in several rural African locations has found a prevalence of hypertension of $11 \%-25 \%$, similar to the prevalence in cities and in high-income countries. A cross-sectional study of 1,500 villagers aged over 15 years in three countries (Tanzania, Malawi, and Rwanda) found 23\% of people with hypertension [8].

Coronary Heart Disease (CHD) cases in Medan City are suffered by a lot of residents in the SubDistrict of Medan Helvetia and Medan Perjuangan (Fig 4). Meanwhile, obesity cases mainly are found in Medan Kota, Medan Marelan and Medan Deli sub-districts (Fig 5).

Prevalence of obesity in the world in two the last decade experienced improvement [9]. In 2030 estimated at about 2.16 billion people adults in the world are overweight, and 1.12 billion will become obese. In Indonesia, the prevalence of central obesity population aged $\geq 15$ years in 2013 was 26.6 percent [3], higher than the prevalence in 2007 (18.8\%) [10]. 


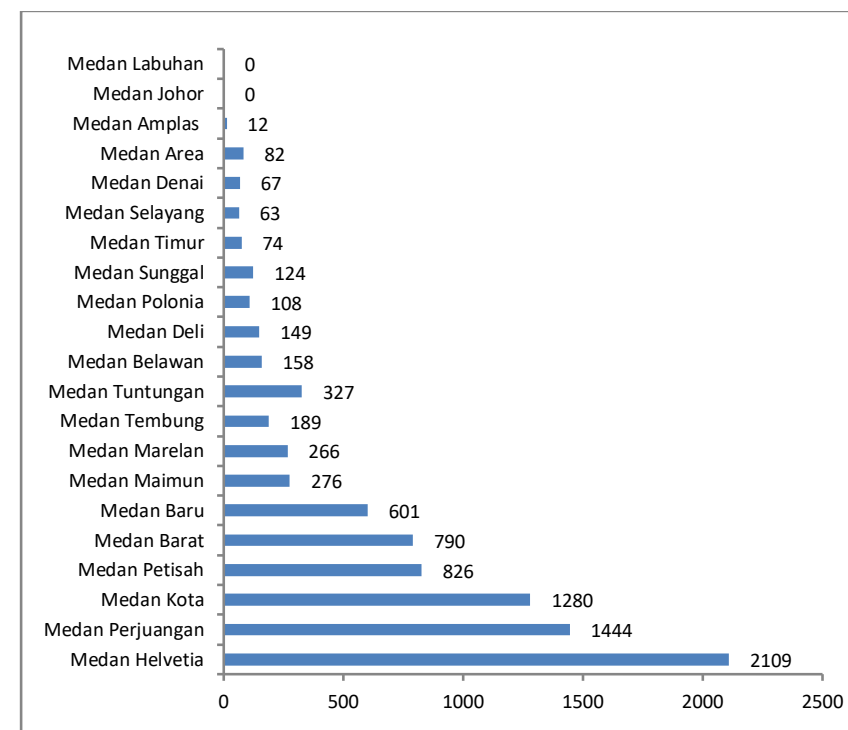

Fig. 4. Number of Hypertension Cases in Medan City 2016

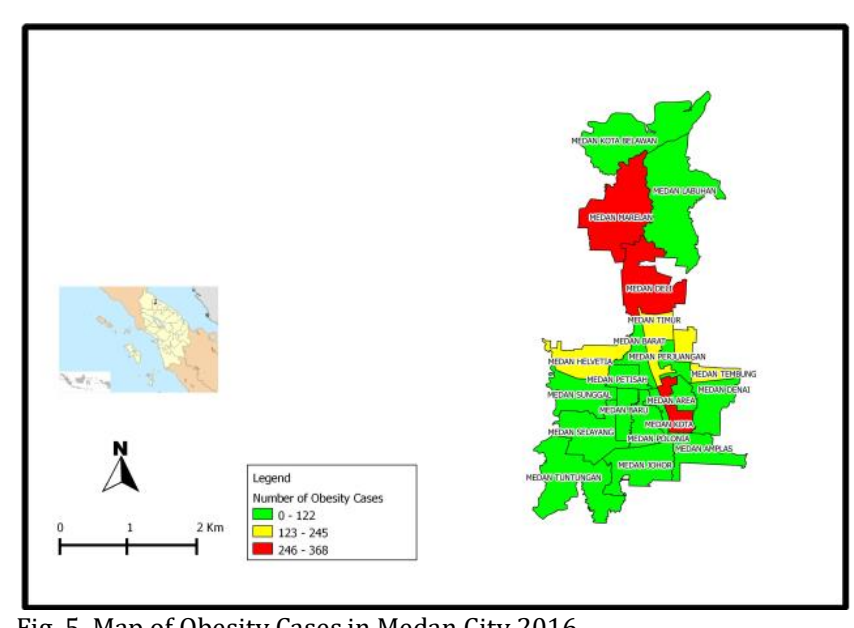

Fig. 5. Map of Obesity Cases in Medan City 2016

\section{CONCLUSION}

Noncommunicable diseases are more and more prevalent in Medan City. In order to reduce the burden of NCDs, comprehensive approaches across the entire disease spectrum are needed, from health promotion, primary prevention, screening of high-risk groups, and early diagnosis to better treatment and rehabilitation. An efficient and proven strategy for reducing NCD burden is risk factor modification. Major modifiable risk factors including high blood pressure, high blood cholesterol, tobacco use, alcohol consumption, and obesity are considered preventable or treatable, and exhibit great potential in reducing NCD burden. The initial step for risk factor modification should be monitoring of prevalence and trends in risk factors. Recently, nationwide or communitybased epidemiological studies have been accumulating descriptive data on NCDs and their risk factors.

\section{ACKNOWLEDGMENT}

This research was supported by Direktorat Riset dan Pengembangan Masyarakat Direktorat Jenderal Penguatan Riset dan Pengembangan, Kementerian Riset, Teknologi dan Pendidikan Tinggi, under contract: 003/SP2H/LT/DRPM/ IV/2017 date 20 April 2017.

\section{REFERENCES}

[1] World Health Organization, "Global Status Report on Non-Communicable Diseases," Geneva, 2011.

[2] Ministry of Health Republic of Indonesia, "Rencana Program Nasional Pencegahan dan Penanggulangan Penyakit Tidak Menular Tahun 2010-2014," Jakarta, 2010.

[3] Badan Penelitian dan Pengembangan Kesehatan, Kementerian Kesehatan RI, "Riset Kesehatan Dasar 2013", Jakarta, 2013.

[4] Kementerian Kesehatan RI, "Rencana Strategis Kementerian Kesehatan Tahun 2010-2014", Jakarta, 2010.

[5] Pusat Data dan Informasi Kesehatan, Kementerian Kesehatan RI, "Gambaran Penyakit Tidak Menular di Rumah Sakit di Indonesia Tahun 2009 dan 2010", Jakarta, 2012.

[6] Dinas Kesehatan Kota Medan, "Profil Kesehatan Kota Medan Tahun 2015, Medan, 2016.

[7] World Health Organization, "Global status report on noncommunicable diseases 2014", Geneva, 2014.

[8] Holmes MD, Dalal S, Volmink J, Adebamowo CA, Njelekela M, et al, "Non-Communicable Diseases in Sub-Saharan Africa: The Case for Cohort Studies". PLoS Med 7(5): e1000244. doi:10.1371/journal.pmed.1000244, 2010.

[9] World Health Organization [WHO]. "Obesity and overweight": report 311. Geneva: World Health Organization, 2013.

[10] Departemen Kesehatan RI. "Laporan hasil riset kesehatan dasar tahun 2007". Jakarta, 2008. 